\title{
Incidence and risk factors in the appearance of heterotopic ossification in spinal cord injury
}

\author{
P Bravo-Payno MD, A Esclarin MD, T Arzoz MD, O Arroyo MD, C Labarta MD \\ Hospital Nacional de Paraplejicos, Toledo, Spain.
}

Heterotopic ossification (HO) is a frequent complication in patients with a spinal cord injury (SCI), although the aetiology is unknown. A study was undertaken of $654 \mathrm{SCI}$ patients with traumatic aetiology, admitted for the first time to the Hospital Nacional de Paraplejicos, Toledo, during 1988 and 1989. Of the total number of patients, $85(13 \%)$ were diagnosed $\mathrm{HO}$ and 569 without $\mathrm{HO}$. The diagnosis was mainly achieved by $\mathrm{x}$-ray studies and clinical signs. From the 569 patients with traumatic aetiology without $\mathrm{HO}, 44$ were selected at random, as were 44 of the 85 patients with $\mathrm{HO}$. The mean time lapse between the occurrence of the accident and admission for patients with HO was 40.79 days (typical deviation $(\mathrm{TD})=45.2$ ), and for patients without $\mathrm{HO}$ was 32.84 $(\mathrm{TD}=38)$ days, resulting in a value of $\mathrm{F}=0.796$ through analysis of variance, which is not a statistically significant variation between the 2 groups. In both groups we have taken account of the following variables: age at time of lesion, lesion level, type of lesion (complete or incomplete), spasticity, urinary tract complications, deep vein thrombosis, important associated injuries occurring at the moment of lesion, time elapsed before admission and the existence of pressure sores. In those SCI patients with $\mathrm{HO}$ the number of ossifications and their localisations were also verified.

By use of the chi square test $\left(\mathrm{X}^{2}\right)$ over all 9 variables which were studied, we found that 3 variables (complete spinal lesion, presence of pressure sores and spasticity) were significantly related to $\mathrm{HO}$ formation. The risk factors appear to be cumulative: the presence of 2 risk factors in the same patient was found to result in $\mathrm{HO}$ appearing in $65 \pm 8 \%(\mathrm{P} \pm \mathrm{SP})$, and when all the risk factors are present in the same patient, $85 \pm 7.9 \%$ had heterotopic ossification.

Eighty two per cent of the patients who presented pressure sores had a time lapse to admission of more than 15 days, against $18 \%$ of those whose time lapse to admission was less than 15 days $\mathrm{X}^{2}[1]=17.8, p<0.001$. For those patients whose time to admission was less than 15 days, and whose progress we could follow from the start, from a total of 7 patients with sores, 6 developed HO while one did not, $\mathrm{X}^{2}[1]=4.2, p<0.05$.

Keywords: spinal cord injury; heterotopic ossification; risk factors.

\section{Introduction}

Heterotopic ossification ( $\mathrm{HO})$ consists in the appearance of new bone within the soft tissues surrounding peripheral joints. ${ }^{1,2}$ Its aetiology is unknown, although various hypotheses exist, including mesenchymal metaplasia,${ }^{3-5}$ bone metabolism, ${ }^{6,7}$ biochemical factors ${ }^{8}$ and joint trauma. ${ }^{9-11}$ It is a complication frequently found in patients with spinal cord injury, and although it can appear in any joint, tends to appear in the hip joints and to a lesser degree, in the shoulders, knees and elbows. ${ }^{12-14}$ It is of variable extent; and between $3 \%-8 \%$ of patients who develop $\mathrm{HO}$ go on to total ankylosis. ${ }^{15.16}$ Parameters indicative of stabilisation and maturity of $\mathrm{HO}$ which have been used include, among others: alkaline phosphatases $^{17.18}$ alkaline phosphatases in combination with high levels of phosphorous, ${ }^{19}$ hydroxyproline, ${ }^{20}$ collagen metabolites $^{21}$ and series study stability in capture of Sr 87.22 
Pharmacological treatment using disodium etidronate has been tried, with the aim of reducing incidence of recurrence of $\mathrm{HO}$ following surgery. ${ }^{23-25}$ Early rehabilitative treatment lowers the incidence, whilst forced sudden movement can increase it, 1,9 but very little acceptable documentation exists, and there is a lack of real criteria for the prediction of which spinal injury patient will be most likely to develop HO.

Considering these premises, we have tried to interrelate a series of parameters which commonly occur in spinal injury patients accompanied by $\mathrm{HO}$, in an attempt to discover if the risk prediction for $\mathrm{HO}$ is possible within the population of SCI patients. If this was the case, then early diagnosis and prophylactic treatment of those patients most at risk could reduce the incidence, severity and the likelihood of complications with $\mathrm{HO}$.

\section{Materials and methods}

A total of 654 SCI patients with traumatic aetiology admitted for the first time to the Hospital Nacional de Paraplejicos in Toledo were examined during 1988 and 1989. Of this total, $85(13 \%)$ were identified as having $\mathrm{HO}$ and 569 no HO. Diagnostic criteria for $\mathrm{HO}$ were clinical signs and the appearances on $\mathrm{x}$-ray examinations.

From these 85 patients with $\mathrm{HO}, 44$ were randomly selected (using random numbers). A sample of 44 other patients without $\mathrm{HO}$ was also selected, using the same technique. All those patients whose time lapse to admission was greater than 180 days were excluded from both groups. Mean time elapsed from accident to hospital admission for patients with $\mathrm{HO}$ was 40.79 days and 32.84 days for those without $\mathrm{HO}$, giving a value of $F=0.796$ using analysis of variance, which does not show a statistically significant variation between the 2 samples (Table I). The following characteristics were studied in all patients of both groups: age at the moment of SCI occurrence; time elapsed from lesion to admission to our hospital; lesion level (cervical, thoracic and lumbar); type of lesion (complete or incomplete); spasticity; complications of the urinary tract; deep vein thrombosis; other trauma occurring at the time of the accident; and pressure sores. For spasticity, we have taken account of patients' treatment using antispasticity drugs, although cases have not been classified according to severity. Two patients with horse tail type lesions were found among those with $\mathrm{HO}$, and 3 in the sample without HO. For complications of the urinary tract, we have taken account of lithiasis, diverticulum, reflux, ectasia, pyelonephritis, and surgical interventions at sphincter level. All pressure sores have been included, although neither their degree nor severity has been taken into account. The number and sites of heterotopic ossification were also studied in the $\mathrm{HO}$ sample.

The statistical study has taken the following factors into account; the arithmetical mean (M), typical deviation (TD) standard error of the mean (SM), and standard deviation in mean differentiation (SD). Percentages $(P)$ have been used for the qualitative variables, with standard percentage error (SP) and the chi square test $\left(\mathrm{X}^{2}\right)$.

\section{Results}

No statistically significant differences were found between the ages of patients with and without $\mathrm{HO}$. The average age of $\mathrm{HO}$ patients was $29.7 \pm 1.4(\mathrm{M} \pm \mathrm{SM}$ ) years (over a range of from 18 to 56 years old), and that of patients without $\mathrm{HO}$ was $33.3 \pm 1.9$ years (from 17 to 64 years old), with a differentiation of the mean ages \pm the standard error in mean differentiation of $3.6 \pm 2.3$, which is not significant.

Twenty four patients were found to have only one $\mathrm{HO}, 17$ with 2 , one with 3 and 2

Table I Mean time lapse lesion/admission in days for $\mathrm{HO}$ and non $\mathrm{HO}$ patients.

\begin{tabular}{lcccc}
\hline & Mean & Typical deviation & Size & Significance \\
\hline With HO & 40.79 & 45.2 & 44 & F = 0.796 NS \\
Without HO & 32.84 & 38 & 44 & \\
\hline
\end{tabular}


with 4 . Hips were the most frequent site of $\mathrm{HO}$, in $36(82 \%)$ patients, and of these 18 (41\%) had both hips involved: $10(23 \%)$ only in the left hip and $8(18 \%)$ only in the right hip. Other locations were: 4 in knees $(9 \%), 3$ in shoulders $(7 \%)$ and one $(2 \%)$ in elbow joints.

Table II shows the factors studied in which no statistically significant differences have been found between patients with and without HO. These are: deep vein thrombosis, complications of the urinary tract, level of lesion and important associated traumas which occurred at the moment of the injury.

Statistical analysis using the chi square test has shown that higher significant statistical differentiation in the following factors exist in patients with $\mathrm{HO}$ : complete spinal lesions $40(91 \%)$, compared with incomplete lesions $4(9 \%)$, together with a higher percentage of complete lesions in $\mathrm{HO}$ patients, $40(56 \%)$ higher than in those without HO 31, $\left.(44 \%), \quad \mathrm{X}^{2}[1]=4.66, \quad p<0.05\right)$ (Table III).
Pressure sores and $\mathrm{HO}$ are clearly interrelated, as can be appreciated from Table III. More patients, $27(61 \%)$ with $\mathrm{HO}$ present pressure sores than do not, 17 $(39 \%)$, and more patients with HO, 27 $(69 \%)$ present pressure sores than do patients without $\mathrm{HO}, 12(31 \%), \mathrm{X}^{2}[1]=9$, $p<0.01$.

Spinal cord injury with spasticity is more prevalent among patients with $\mathrm{HO}$ (30 $(68 \%))$ against $14(32 \%)$ without spasticity. Table III also shows that more patients with HO present spasticity, $30(67 \%)$, against those without $\mathrm{HO}, 15(33 \%), \mathrm{X}^{2}[1]=8.9$, $p<0.01$.

The following significant risk factor variables have been found in relation to the appearance of HO: complete spinal lesion, pressure sores and spasticity. The relationship of these factors according to their presentation in patients with and without $\mathrm{HO}$ was studied. The number of risk factor variables on a scale of $0-3$ for the sum of the 2 samples has therefore been shown. This

Table II Non significant variables

\begin{tabular}{lrrl}
\hline Variables & $\begin{array}{c}\text { With HO } \\
\mathrm{N}=44\end{array}$ & $\begin{array}{c}\text { Without HO } \\
\mathrm{N}=44\end{array}$ & Significance \\
\hline Lesion level & & & \\
$\quad$ Cervical & $21(48 \%)$ & $17(39 \%)$ & $\mathrm{X}^{2}[2]=1 \mathrm{NS}$ \\
$\quad \begin{array}{l}\text { Thoracic } \\
\text { Lumbar }\end{array}$ & $20(45 \%)$ & $22(50 \%)$ & \\
Vein thrombosis & $14(32 \%)$ & $5(11 \%)$ & \\
Urinary tract complications & $14(32 \%)$ & $8(18 \%)$ & $\mathrm{X}_{2}[1]=0.52, \mathrm{NS}$ \\
Associated trauma & $24(55 \%)$ & $21(48 \%)$ & $\mathrm{X}^{2}[1]=1.5, \mathrm{NS}$ \\
\hline
\end{tabular}

Table III Risk factors and heterotopic ossification

\begin{tabular}{|c|c|c|c|}
\hline Risk factors & With $\mathrm{HO}$ & Without $\mathrm{HO}$ & Significance \\
\hline $\begin{array}{l}\text { Type of lesion } \\
\text { Complete } \\
\text { Incomplete }\end{array}$ & $\begin{array}{r}40 \\
4\end{array}$ & $\begin{array}{l}31 \\
13\end{array}$ & $\mathrm{X}^{2}[1]=4.66, p<0.05$ \\
\hline $\begin{array}{l}\text { Pressure sores } \\
\text { With sores } \\
\text { Without sores }\end{array}$ & $\begin{array}{l}27 \\
17\end{array}$ & $\begin{array}{l}12 \\
32\end{array}$ & $\mathrm{X}^{2}[1]=9, \quad p<0.01$ \\
\hline $\begin{array}{l}\text { Spasticity } \\
\text { With spasticity } \\
\text { Without spasticity }\end{array}$ & $\begin{array}{l}30 \\
14\end{array}$ & $\begin{array}{l}15 \\
29\end{array}$ & $\mathrm{X}^{2}[1]=8.9, \quad p<0.01$ \\
\hline
\end{tabular}


runs from 0 for patients who do not have any risk factors, to 3 for those with all 3 factors (Table IV), with a significant statistical differentiation of $\mathrm{X}^{2}[3]=26.8, \quad p<$ 0.001 . As can be observed from this table, risk factors are cumulative. With 2 risk factors there is a $65 \pm 8 \% \quad(\mathrm{P} \pm \mathrm{SP})$ probability of $\mathrm{HO}$ occuring, and with 3 factors $85 \pm 7.9 \%$ probability of $\mathrm{HO}$.

Table V shows that the time elapsed before an SCI patient is admitted to a specialised unit is related to the appearance of pressure sores. Of the 39 patients who presented with pressure sores, $32(82 \%)$ had taken more than 15 days following the accident before being admitted to our hospital, against $7(18 \%)$ who took less than 15 days, $\mathrm{X}^{2}[1]=17.8, p<0.001$.

As can be observed in Table VI, for patients whose time lapse to admission was less than 15 days, and whose development

Table IV Relationship of risk factors and heterotopic ossification in SCI

\begin{tabular}{lrrc}
\hline $\begin{array}{l}\text { Risk factors } \\
0-3\end{array}$ & $\begin{array}{r}\text { With HO } \\
\mathrm{n}=44\end{array}$ & $\begin{array}{r}\text { Without HO Patients } \\
\mathrm{n}=44\end{array}$ & \begin{tabular}{c}
$\mathrm{n}=88$ \\
\hline With 0
\end{tabular} \\
With 1 & $1(25 \%)$ & $3(75 \%)$ & 4 \\
With 2 & $6(18 \%)$ & $27(82 \%)$ & 33 \\
With 3 & $17(85 \%)$ & $11(35 \%)$ & 31 \\
\hline
\end{tabular}

$\mathrm{X}^{2}[3]=26.8, p<0.001$ could be followed from the first, of the 17 with $\mathrm{HO}, 6(35 \%)$ presented pressure sores, compared with one patient $(4.5 \%)$ who developed pressure sores of the $(n=22)$ patients without $\mathrm{HO}, \mathrm{X}^{2}[1]=4.2, p<0.05$, giving a correlation pressure sores/ $\mathrm{HO}$.

Patients with complete lesions and $\mathrm{HO}$ $(n=40)$ were more likely to have pressure sores $24(60 \%)$ than were patients with complete lesions without $\mathrm{HO}(\mathrm{n}=31), 9$ $(29 \%), \mathrm{X}^{2}[1]=5.5, p<0.05$.

\section{Discussion}

According to the different series, the incidence of $\mathrm{HO}$ varies between $12 \%$ and $40 \%$ of patients. ${ }^{9,13-15,26,27}$ Our incidence of $13 \%$ is similar to that given by other authors in recent years. ${ }^{28,29}$ The period of the highest frequency of occurrence is from one to 4 months following the spinal lesion, although it can occur even after a year. ${ }^{23,25}$

The presentation of $\mathrm{HO}$ has been correlated with infections of the urinary tract, pressure sores, spasticity, vigorous manipulation, alterations in the innervation of the sympathetic nervous system, changes in collagen and in bone metabolism, metabolic acidosis and disturbances in ionic balance, vascular alterations, and the time that has elapsed before admission to a specialised unit, etc. ${ }^{19,13,21,22,28-30}$ We believe that localised multifactorial mechanisms must exist,

Table V Relation of time lapse from lesion to admission, to number of patients with pressure sores

\begin{tabular}{lccc}
\hline Time to admission & With sores & Without sores & Significance \\
\hline Less than 15 days & 7 & 32 & $\mathrm{X}^{2}[[1]=17.8, p<0.001$ \\
More than 15 days & 32 & 17 & \\
Total & 39 & 49 & \\
\hline
\end{tabular}

Table VI Relation of time to admission less than 15 days and number of pressure sores in patients with and without $\mathrm{HO}$

\begin{tabular}{lccc}
\hline & With HO & Without HO & Significance \\
\hline With sores & 6 & 1 & $\mathrm{X}^{2}[1]=4.2, p<0.05$ \\
Without sores & 11 & 21 & \\
Total & 17 & 22 & \\
\hline
\end{tabular}


together with other general factors resulting from the neurological lesion and its metabolic and vegetative repercussions. Our study has found 3 risk factors: complete transverse spinal lesion, pressure sores and spasticity. Most authors find a higher incidence of $\mathrm{HO}$ in patients with complete transverse spinal lesions, than in those whose lesions are incomplete. ${ }^{14,27,29} \mathrm{Al}$ though pressure sores can appear before or after the onset of $\mathrm{HO}$, they usually do so beforehand, and are generally caused by lack of special care during the acute phase, if this is spent in a non specialised hospital. Several authors have emphasised the importance of rapid admission to a specialised hospital, as they believe that this diminishes the number of patients who subsequently develop HO. ${ }^{1,9}$ Our study has found time lapse to admission to a specialised hospital to be related to pressure sores: an increase in delay giving rise to an increase in the number of pressure sores. Another finding was that if these sores appear during the early phases of the condition, then this influences the onset of $\mathrm{HO}$. We understand this to mean that the same aetiology could play a role in both the development of sores and the formation of $\mathrm{HO}$, ie pressure, severe friction or muscular trauma, together with lack of special care, with tissue infection perhaps playing a role following development of a pressure ulcer. Heterotopic ossification could be due to the presence of pressure sores, if the infection penetrates the deep tissues down to bone. ${ }^{31}$

Lal et $a l^{29}$ found that $84 \%$ of their patients with $\mathrm{HO}$ present had spasticity, against $54 \%$ of those without HO. Our study has also found statistically significant differences, showing greater predominance of spasticity in $\mathrm{HO}$ than in non $\mathrm{HO}$ patients. Whilst the onset of spasticity usually occurs during the first few weeks after the spinal lesion, HO develops after several weeks or months. ${ }^{29}$

Trauma to the joints and violent manipulation, above all of those patients suffering intense spasticity, have been stated to be risk factors for the appearance of $\mathrm{HO}$ by several investigators. ${ }^{9,22}$ We believe that trauma, manipulations and even intense spasticity in patients lacking sensitivity can give rise to the formation of haematomas and para-articular microhaematomas, which then calcify and ossify through metaplasia of the mesenchymal cells into osteoblasts.

The risk factors encountered appear to be cumulative. The presence of 2 factors gives rise to the probability of $65 \pm 8 \%$ of developing $\mathrm{HO}$, this rising to $85 \pm 7.9 \%$ for 3 factors. For these cases, the possibility of prophylactic treatment using disodium etidronate should be considered.

Correct rehabilitative medical treatment from the moment of occurrence of the lesion diminishes some risk factors intervening in the aetiology of $\mathrm{HO}$.

\section{References}

1 Damansky M (1961) Heteropic ossification in paraplegia. J Bone Joint Surg 2: 286-289.

2 Hardy AG, Dickson JW (1963) Pathological ossification in traumatic paraplegia. J Bone Joint Surg 45B: 76-87.

3 Ostrowski K, Wlodarski K (1971) Induction of heterotopic bone formation. In: Comar CL, Bronner J, editors. Biochemistry and Physiology of Bone. Vol III. Academic Press, New York: 3502-3507.

4 Buring K (1975) On the origin of cells in heterotopic bone formation. Clin Orthop 110: 293-302.

5 Christine MI, Smith BA, Jefferson AA, Timperley MA, Path, Watson N (1983) Osseous metaplasia: a late pathological finding within the scar tissue formed following spinal injury. Paraplegia 21: 380-387.

6 Chantraine A (1971) Clinical investigation of bone metabolism in spinal cord lesions. Paraplegia 8: 253-2595.

7 Bergman P, Heilman A, Schoutens A, Paternot J, Tricot A (1978) Longitudinal study of calcium and bone metabolism in paraplegic patients. Paraplegia 15: 147-150.

8 Farley JR, Baylink DJ (1982) Purification of a skeletal growth factor from human bone. Biochemistry 21: 3502-3507.

9 Silver JR (1969) Heterotopic ossification: a clinical study of its possible relationship to trauma. Paraplegia 7: 220-230.

10 Kaplan PE, Gandhavadi B, Richards L, Goldschnidt J (1978) Calcium balance in paraplegic patients: influence of injury duration and ambulation. Arch Phys Med Rehabil 59: 447-450.

11 Izumi K (1983) Study of ectopic bone formation in experimental spinal cord injured rabbits. Paraplegia 6: 351-363. 
12 Smith R (1975) Myositis ossificans progressiva. A review of current problems. Semin Arthritis Rheum 4: $369-381$.

13 Mazaira J, Romero M, Soria M (1978) Osificacionnes paraarticulares en los sindromes de lesion medular (revision de 482 casos). Rehabilitacion 12: 297-305.

14 Hernandez AM, Forner JV, De la Fuente T, Miro R (1978) The para-articular ossifications in our paraplegics and tetraplegics: a survey of 704 patients. Paraplegia 16: 272-275.

15 Wharton GW, Morgan TH (1970) Ankylosis in the paralyzed patient. J Bone Joint Surg 52A, 1: 105-112.

16 Chantraine A, Minaire P (1981) Para-ostheopathics: a new theory and mode of treatment. Scand J Rehabil Med 13: 31-37.

17 Furman R, Nicholas JJ, Jivoff L (1970) Elevation of the serum alkaline phosphatase coincident with ectopic-bone formation in paraplegic patients. J Bone Joint Surg 52 A: 1131-1137.

18 Nicholas JJ (1973) Ectopic bone formation in patients with spinal cord injury. Arch Phys Med Rehabil 54: $354-358$.

19 Kim SW, Charter RA, Chai CJ, Kim SK, Kim ES (1990) Serum alkaline phosphatase and inorganic phosphorus values cord injury patients with heterotopic ossification. Paraplegia 28: 441-447.

20 Benassy J, Combelles FR (1971) Osteomes. Tentatives therapeutiques. Ann Med Phys (Paris) 14: 467-475.

21 Rodriguez GP, Claus Walker J, Kent MC, Garza HM (1989) Collagen metabolic excretion as a predictor of bone and skin-related complications in spinal cord injury. Arch Phys Rehab 70: 442-444.

22 Rossier AB, Bussat P, Infante F, Zender R, Courvoisier B, Muhein G (1973) Current facts on para-osteoarthropathy (PAO). Paraplegia 11: 36-78.

23 Stover SL, Hahn HR, Miller JM III (1976) Disodium etidronate in the prevention of heterotopic ossification following spinal cord injury. (Preliminary report). Paraplegia 14: 146-156.

24 Garland DE, Alday B, Venos KG, Vogt JC (1983) Diphosphate treatment for heterotopic ossification in spinal cord injury patients. Clin Orthop Rel Res 176: 197-200.

25 Freed JH, Hahn H, Menter R, Dillon T (1982) Use of three-phase bone scan in early diagnosis of heterotopic calcification (HO) in an evaluation of Didronel therapic. Paraplegia 20: 208-216.

26 Abramson A, Kamberg G (1949) Spondylitis pathological ossification and calcification associated with spinal cord injury. J Bone Joint Surg 31 A: 275-282.

27 Scher AT (1976) The incidence of ectopic bone formation in post-traumatic paraplegic patients of different racial groups. Paraplegia 14: 202-206.

28 Gomez V, Moros G, Dueso S (1985) Influencia del control de la acidosis metabolica y disturbios del balannce ionico en la incidencia de P.A.O en los lesionados medulares. Rehabilitacion 19: 451-456.

29 Lal S, Hamilton BB, Heinemann A, Betts HB (1989) Risk factors for heterotopic ossification in spinal cord injury. Arch Phys Med Rehabil 70: 387-390.

30 Benassy J, Mazabraud A, Diverres J (1963) L'ostèogenèse neurogène. Rev Chir Orthop 49: 95-116.

31 Guttmann L (1981) Calcificaciones y osificaciones de los tejdios blandos. En Lesiones Medulares. Tratamiento global e investigacion. $1^{a}$ ed Barcelona. Editorial JIMS: 237-243. 